Cahiers $d u$ MONDE RUSSE

\section{Cahiers du monde russe}

Russie - Empire russe - Union soviétique et États indépendants

$49 / 4 \mid 2008$

Destins individuels et terreur. Jeunesse dans la société post-stalinienne

\title{
Citizenship, Deviance, and Identity
}

Soviet youth newspapers as agents of social control in the Thaw-era leisure campaign

\section{GLEB Tsipursky}

\section{(2) OpenEdition}

\section{Journals}

Édition électronique

URL : https://journals.openedition.org/monderusse/9499

DOI : $10.4000 /$ monderusse. 9499

ISSN : $1777-5388$

Éditeur

Éditions de l'EHESS

\section{Édition imprimée}

Date de publication : 28 décembre 2008

Pagination : 629-650

ISBN : 978-2-7132-2197-2

ISSN : $1252-6576$

Référence électronique

GLEB Tsipursky, « Citizenship, Deviance, and Identity », Cahiers du monde russe [En ligne], 49/4 | 2008, mis en ligne le 01 janvier 2008, consulté le 03 septembre 2022. URL : http://journals.openedition.org/ monderusse/9499; DOI : https://doi.org/10.4000/monderusse.9499 


\title{
CITIZENSHIP, DEVIANCE, AND IDENTITY
}

\author{
Soviet youth newspapers as agents of social control \\ in the Thaw-era leisure campaign*
}

\begin{abstract}
"Why is it inappropriate to dance 'stylishly'? How should we view young people who sport mustaches and are rude to women? Is it uncultured for a girl to put on lipstick and powder her face?"1 These questions, posed by Soviet youth in political lectures, suggest that issues of personal appearance and behavior inspired serious discussion among the young generation. Indeed, during the Thaw - the period following Stalin's death in 1953 and encompassing the rule of N.S. Khrushchev from 1955 - , "one's look was a matter of principle” for many young people, since "the narrowness of one's pants" could lead to expulsion from the university. ${ }^{2}$ The potentially severe repercussions of supposedly amoral appearance illuminates the attention paid by the post-Stalin Communist Party to managing youth identity, which was considered crucial to the construction of the "ideal" communist citizen. ${ }^{3}$
\end{abstract}

* I would like to extend my sincere gratitude to Donald J. Raleigh, whose thoughtful insights,
as well as reading of multiple drafts, helped shape this project from the very beginning. I also
thank Emily Baran, Chad Bryant, Jeffrey Jones, Catriona Kelly, Louise McReynolds, Joan
Neuberger, Jennifer Parks, Michael Paulauskas, the participants of the 2008 Social Science
Research Council "Violence in Eurasia" seminar, and the two anonymous reviewers from this
journal, all of whose constructive criticism enabled a substantially stronger final article. A
Fulbright-Hays research abroad grant and a University of North Carolina at Chapel Hill travel
grant supported the necessary primary source research in Moscow, where the staff at the
Komsomol archive proved especially helpful.

1.RGASPI (Rossiiskii gosudarstvennyi arkhiv sotsiial'no-politicheskoi istorii), f. M-1, Molodezhnyi otdel, op. 32, Agitprop, d. 814,1. 10-11.

2. A.S. Kozlov, "Kozel na sakse": i tak vsiu zhizn" (["A goat at the sax": For my whole life] (M.: Vagrius, 1998), 103.

3. I define "identity" as encompassing one's worldview and values. For the problems with the unreflective use of this term, see Rogers Brubaker and Frederick Cooper, "Beyond 'Identity'," Theory and Society, 29, 1 (2000): 1-47. 
Nonetheless, the uncertainty implied by such questions at lectures reveals the confusion over this essential ideological project.

The mid-1950s, a period characterized by Khrushchev's rejection of Stalinism and attempt to return to Leninist norms, most notably in the Secret Speech of 1956, witnessed a renewed effort to attain the communist utopia. As part of this drive, the Party launched a sweeping campaign in 1954 to make model communist citizens, New Soviet People - faithful to socialism and the Party, cultured and moral, collectivist and patriotic - , by regulating how young people behaved in their free time. This Janus-faced initiative combined the offering of much increased engaging leisure options such as artistic creativity with the symbolic violence ${ }^{4}$ of public censure by newspapers and at Komsomol ${ }^{5}$ meetings, and occasional physical violence of Komsomol patrols. The present article focuses on the role of the Komsomol press in the coercive aspects of the leisure policy. ${ }^{6}$

The Party paid extensive attention to its policy toward young people because of their prominent place in Marxist-Leninist theory: they were supposed to build the communist utopia that represented the primary goal of the Soviet experiment. Still, before the late 1980s, few non-Soviet anglophone historians examined Soviet youth. ${ }^{7}$ The Gorbachev era inspired a new subfield of youth studies, ${ }^{8}$ while the increased research opportunities and new methodologies in the 1990s resulted in groundbreaking monographs in this area..$^{9}$ My work in particular engages with

4. Following Dipesh Chakrabarty's view of symbolic violence as coercion by means other than physical force, see his Provincializing Europe: Postcolonial Thought and Historical Difference (Princeton: Princeton University Press, 2000), 1-27.

5. The Komsomol, the mass organization for fourteen-to-twenty-eight-year-olds dedicated to socializing youth, grew rapidly in the 1950 s, with half of all those eligible becoming members by 1958. With participation essential for those who wished to go to college or join the Party, most members belonged to the middle class. See Allen Kassof, The Soviet Youth Program: Regimentation and Rebellion (Cambridge: Harvard University Press, 1965), 14-18.

6. My broader research project also looks at state-sponsored engaging leisure offerings in the late Stalin and Khrushchev eras. For more on such leisure, in particular artistic creativity, see Bella Ostromoukhova, "Le Dégel et les troupes amateur: Changements politiques et activités artistiques des étudiants, 1953-1970," Cahiers du Monde russe et soviétique, 47, 1-2 (2006): 303-325; Susan Costanzo, "Reclaiming the Stage: Amateur Theater-Studio Audiences in the Late Soviet Era," Slavic Review, 57, 2 (1998): 398-424; Idem, "Amateur Theaters and Amateur Publics in the Russian Republic, 1958-71," The Slavonic and East European Review, 86, 2 (2008): 372-394; L.P. Solntseva, ed., Samodeiatel'noe khudozhestvennoe tvorchestvo v SSSR, ocherki istroii, 1930-1950 gg. [The history of amateur arts in the USSR, 1930-1950] (M.: Gosudarstvennyi institut iskusstvoznaniia, 1995).

7. Exceptions include Kassof, The Soviet Youth..., and Ralph T. Fisher, Pattern for Soviet Youth (New York: Columbia University Press, 1959).

8. James Riordan, ed., Soviet Youth Culture (Basingstoke - Hampshire: Macmillan, 1989), and John Bushnell, Moscow Graffiti: Language and Subculture (Boston: Unwin Hyman, 1990).

9. Hillary Pilkington, Russia's Youth and its Culture: A Nation's Constructors and Constructed (New York: Routledge, 1994); Peter Konecny, Builders and Deserters: Students, State, and Community in Leningrad, 1917-1941 (Montreal: McGill-Queen's University Press, 1999); Anne E. Gorsuch, Youth in Revolutionary Russia: Enthusiasts, Bohemians, Delinquents (Bloomington: Indiana University Press, 2000); Igal Halfin, From Darkness to Light: Class, Consciousness, and Salvation in Revolutionary Russia (Pittsburgh: University of Pittsburgh Press, 2000); Catriona Kelly, Children's World: Growing Up in Russia, 1890-1991 (New 
recent scholarship on post-1945 youth policy that analyzes state coercion not only under Stalin, but also during the Thaw, redefining the period as a time of repression as well as reform. ${ }^{10}$ This article helps fill a historiographical gap in this literature and advance our knowledge of the Khrushchev era as a whole by investigating the public discourse relating to these policies. Furthermore, it converses with the surprisingly sparse work on the Soviet 1950s and 1960s which, for the most part, previously featured works by political scientists; ${ }^{11}$ the historical discipline only recently commenced on a richer and more sophisticated investigation of this period, using the methods of cultural, social, and new political history. ${ }^{12}$

Since newspapers served as the main source for public information and acted as the voice of the government, the Komsomol press played a critical role in the implementation of the new campaign. The article sheds light on the function of newspapers as social control agents in the leisure initiative by examining

Haven: Yale University Press, 2007); Steven L. Solnick, Stealing the State: Control and Collapse in Soviet Institutions (Cambridge: Harvard University Press, 1998). Recent Russian scholarship includes, among others, L.V. Silina, Nastroeniia sovetskogo studenchestva, 19451964 [The opinions of Soviet students, 1945-1964] (M.: Russkii mir, 2004); A.Z. Vakser, Leningrad poslevoennyi: 1945-1982 gody (SPb.: Izdatel'stvo Ostrov, 2005); V.I. Isaev, Molodezh' Sibiri v transformiruiushchemsia obshchestve: usloviia i mekhanizmy sotsializatsii (1920-1930-e gg.) [Siberian youth in a transforming society: The conditions and mechanisms of socialization (1920s-1930s)] (Novosibrisk: Gosudarstvennyi universitet Novosibirska, 2003).

10. Sheila Fitzpatrick, "Social Parasites: How Tramps, Idle Youth, and Busy Entrepreneurs Impeded the Soviet March to Communism," Cahiers du Monde russe et soviétique, 47, 1-2 (2006): 1-32; Juliane Fürst, "The Arrival of Spring? Changes and Continuities in Soviet Youth Culture and Policy between Stalin and Khrushchev," in Polly Jones, ed., The Dilemmas of DeStalinization: Negotiating Cultural and Social Change in the Khrushchev Era (New York: Routledge, 2006), 135-153; Idem., "The Importance of Being Stylish: Youth, Culture and Identity in Late Stalinism," in Juliane Fürst, ed., Late Stalinist Russia: Society between Reconstruction and Reinvention (New York: Routledge, 2006), 209-230; Mark Edele, "Strange Young Men in Stalin's Moscow: The Birth and Life of the Stiliagi, 1945-1953," Jahrbücher für Geschichte Osteuropas, 50.1 (2002): 37-61; Oleg Kharkhordin, The Collective and the Individual in Russia: A Study of Practices (Berkeley: University of California Press, 1999), 279-302; N.A. Mitrokhin, Russkaia partiia: Dvizhenie russkikh natsionalistov v SSSR, 1953-1985 gody [The Russian party: The movement of Russian nationalists in the USSR, 1953-1985] (M.: Novoe literaturnoe obozrenie, 2003); Brian LaPierre, "Private Matters or Public Crimes: The Emergence of Domestic Hooliganism in the Soviet Union, 1939-1966," in Lewis H. Siegelbaum, ed., Borders of Socialism: Private Spheres of Soviet Russia (New York: Pallgrave Macmillan, 2006), 191-207.

11. See, among others, Carl A. Linden, Khrushchev and the Soviet Leadership, 1957-1964 (Baltimore: Johns Hopkins Press, 1966). A notable exception is Stephen F. Cohen, Alexander Rabinowitch and Robert Sharlet, eds., The Soviet Union since Stalin (Bloomington: Indiana University Press, 1980).

12. For example, see Jones, The Dilemmas...; Iu. Aksiutin, Khrushchevskaia "Ottepel" $i$ obshchestvennye nastroeniia v SSSR v 1953-1964 gg. [The Khrushchev "Thaw" and public opinion in the USSR, 1953-1964] (M.: Rosspen, 2004); Melanie Ilich, Susan E. Reid and Lynne Attwood, eds., Women in the Khrushchev Era (New York: Palgrave Macmillan, 2004); William Taubman, Khrushchev: The Man and His Era (New York: W.W. Norton, 2003); Josephine Woll, Real Images: Soviet Cinema and the Thaw (New York: I.B. Tauris, 2000); Elena Iur'evna Zubkova, Russia After the War: Hopes, Illusions, and Disappointments, $1945-$ 1957(Armonk: M.E. Sharpe, 1998); Mitrokhin, Russkaia partiia... 
Komsomol'skaia pravda (KP) and Moskovskii komsomolets (MK). ${ }^{13}$ Though scholars disagree over the extent to which the Party controlled the press during the Thaw, new research suggests that journalists, overall, strongly supported Khrushchev's reformist project and willingly participated in the drive to construct model communist citizens; ${ }^{14}$ archival documents also imply that youth newspapers followed the Komsomol's official policy on the issue of youth misbehavior. ${ }^{15}$ This essay work draws on 1005 relevant stories gathered from a close reading of a few weeks every 3 to 4 months from 1950 to 1964 , in order to get a sense of the late Stalin as well as the Khrushchev years. Its approach to newspaper discourse regards it as embodying the Party's idealized view of how young people should conceptualize their lives. ${ }^{16}$ In addition, the article considers Soviet archival documents, literature, surveys, and memoirs.

Building on these sources, I argue that the Khrushchev leadership's leisure initiative relied on social mobilization and collective opprobrium as its premier tools of social control - which necessitated the discursive presentation of youth as activist citizens - , and led to the unintended consequence of the growth of youth agency. The use of public censure and mass mobilization resulted from the rejection of the widespread utilization of direct governmental coercion and turn to "infrastructural power" in the post-Stalin era. ${ }^{17}$ Just as importantly, it reflected the attempt to transfer governing functions from the state to the citizenry as a way of moving to the goal of societal self-management in the communist utopia. ${ }^{18}$ The dependence on social activation and public criticism for social control necessitated

13. KP the central organ of the Komsomol, wrote on issues of national significance. Read by publicly engaged young people and some adults throughout the Soviet Union, $K P$ had a daily press run of 6,000,000 in 1961. MK, the newspaper of the Moscow Komsomol city committee, popular among Moscow youth, reflected national-level concerns through the lens of local affairs and had daily publication figures of 100,000 in 1961. See Vsesoiuznaia knizhnaia palata, Letopis' periodicheskikh izdanii SSSR [The chronicle of periodical publications in the USSR] (M.: Izdatel’stvo “Kniga”, 1967), 9, 157.

14. I am indebted to Thomas C. Wolfe for my understanding of Khrushchev-era journalists: Governing Soviet Journalism: The Press and the Socialist Person after Stalin (Bloomington: Indiana University Press, 2005), 33-70.

15. For example, $K P$ sent the Komsomol Central Committee (KCC) a long list of planned articles dealing with alcoholism as part of the early Thaw campaign against alcoholism: RGASPI, f. M-1, op. 3, Biuro KCC, d. 841,1. 83-84.

16. In consequence, the essay treats published letters as corresponding to the range of opinion allowed by the state. Unfortunately, the archives of $K P$ and $M K$ are unavailable for research, making it impossible to judge how the editorial board chose which letters to publish, or to what extent newspaper staff edited the letters.

17. Michael Mann defines "infrastructural power" as the state's capacity to effect changes in everyday life without the use of direct coercive force, via the state's penetration into society: see his "The Autonomous Power of the State: Its Origins, Mechanisms and Results," in John H. Hall, ed., States in History (New York: B. Blackwell, 1986), 109-136.

18. The Khrushchev Party expressed this goal in many forums: for example, see the PCC's 1960 resolution on propaganda: Voprosy ideologicheskoi raboty [Issues in ideological work] (M.: Gospolitizdat, 1961), 144-158. George Breslauer thoughtfully identified the Khrushchev leadership's goal in "Khrushchev Reconsidered" in Cohen, Rabinowitch and Sharlet, eds., The Soviet Union, 50-70. 
a shift in the presentation in the press of the New Soviet Person. He or she turned from the passive subject in the newspapers of the late Stalin era, meekly receiving Stalin's gifts, ${ }^{19}$ into a Khrushchev-era activist citizen who took initiative in organizing leisure and punished those who engaged in free-time behavior labeled as immoral. ${ }^{20}$ Nevertheless, press rhetoric proved contradictory, leaving room, perhaps deliberately, for negotiation over the definition of deviance. The resultant discursive ambiguity, by encouraging young people to develop an autonomous identity, led to the growth of youth agency ${ }^{21}$ and may have undermined the creation of the communist utopia.

\section{The leisure campaign: Context and background}

Sometime in late August or early September 1955, each primary Komsomol cell, ranging from massive factory-wide organizations of over a thousand members to miniscule three-member groups, received a letter from the Komsomol Central Committee (KCC). Stamped "not for publication," this closed letter, intended for discussion only at Komsomol meetings, condemned "hooliganism, drunkenness, licentiousness," and demanded the intensification of the struggle with these "repulsive phenomena." 22 This represented the first time that the KCC utilized a closed missive, and indicated the gravity of the issue of deviation from acceptable norms, which the Khrushchev leadership perceived as fundamental to obstructing the road to the ideal communist future.

The letter mirrored broader post-Stalin official language, which sought to equate the cultural practices ${ }^{23}$ of hooligans and stiliagi — "westernized" Soviet youth — and

19. For Stalinist newspapers, see Jeffrey Brooks, Thank You, Comrade Stalin! Soviet Public Culture from Revolution to Cold War (Princeton: Princeton University Press, 2000).

20. I draw on the labeling theory of deviance, which posits that "deviants" become "deviant" when those with enough power succeed in imposing this label on them: see Stephen Pfohl, Images of Deviance and Social Control: A Sociological History (New York: McGraw-Hill, 1994), 345-398, and Stuart H. Traub and Craig B. Little, eds., Theories of Deviance (Itasca, IL: F.E. Peacock Publishers, Inc., 1985), 277-332. For a work that widely utilizes the labeling theory approach in the Soviet context, see Brian LaPierre, Defining, Policing, and Punishing Hooliganism in Khrushchev's Russia (Ph. D. dissertation, University of Chicago, 2006).

21. I use "agency" to refer to self-willed, voluntary motivation for behavior, based on Arjun Appadurai's discussion of agency in his Modernity at Large: Cultural Dimensions of Globalization (Minneapolis: University of Minnesota Press, 1996), 7.

22. RGASPI, f. M-1, op. 3, d. 878,1. 79.

23. I do not use the term "subculture" due to this concept's indelible association with homogeneous, tightly bounded groups that practice class-based resistance: Andy Bennett and Keith Kahn-Harris, "Introduction," in Andy Bennett and Keith Kahn-Harris, eds., After Subculture: Critical Studies in Contemporary Youth Culture (New York: Palgrave Macmillan, 2004), 1-18. However, the models of "lifestyles" or "neo-tribes" presented by advocates of this postsubcultural approach have been effectively undermined as lacking adequate appreciation of local contexts: see an introduction to a special journal edition, Hilary Pilkington and Richard Johnson, "Peripheral Youth: Relations of Identity and Power in Global/Local Context," European Journal of Cultural Studies, 6, 3 (2003): 259-283. 
place both outside the limits of public acceptance. ${ }^{24}$ A long-held concern for the Party, "hooliganism," 25 one supposedly deviant way of spending free time, denoted the conduct of mostly working-class male individuals. The typical hooligan fought frequently, drank excessively, stole, harassed and abused women, cursed and smoked, and in general "disturbed the peace." 26 In the immediate postwar period, young middle-class men and women fascinated with western European and American popular culture appeared in the USSR. ${ }^{27}$ Though consisting of a variety of evolving lifestyle groups, they often had similar consumption-oriented cultural practices and semiotic markers, including: dressing in clothes they imagined to resemble those worn in western Europe and America, ${ }^{28}$ frequenting restaurants, drinking a great deal of cocktails and whiskey, listening to forbidden jazz and rock, and imitating the twist and boogie-woogie in dance squares. ${ }^{29}$ These youth, homogenized with the deprecating label of stiliagi, or "style-obsessed," by the official media, were perceived as violating official norms of style and behavior, and caused great concern among the authorities over the consequences of opening up the borders of society to "foreign bourgeois" influence. ${ }^{30}$ Such Soviet developments occurred in a postwar pan-European and North American context of growing apprehension over the impact of gangs, beatniks, Teddy Boys, Mods and Rockers, Halbstarken, and

24. I place "western" in quotation marks and do not capitalize western Europe, as doing so functions to homogenize a widely varied region and set of historical experiences, as well as make claims to a defined, inherent separation between "western" and "eastern." My view is informed by Martin W. Lewis and Karen E. Wigen, The Myth of Continents: A Critique of Metageography (Berkley: University of California Press, 1997), 1-9.

25. For the origins of the term "hooliganism" in Russia, see Joan Neuberger, Hooliganism: Crime, Culture, and Power in St. Petersburg, 1900-1914 (Berkeley: University of California Press, 1993), 1-3.

26. For more on hooliganism in the Khrushchev era, see Brian LaPierre, Defining, Policing, and Punishing Hooliganism in Khrushchev's Russia, and V.A. Kozlov, Mass Uprisings in the USSR: Protest and Rebellion in the Post-Stalin Years, trans. Elaine M. MacKinnon (Armonk: M.E. Sharpe, 2002).

27. For scholarly studies of such youth, see Edele, "Strange Young Men"; Fürst, "The Importance..."; Kristin Roth-Ey, Mass Media and the Remaking of Soviet Culture, 1950s1960 s (Ph.D. dissertation, Princeton University, 2003), 46-98; Richard Stites, Russian Popular Culture: Entertainment and Society since 1900 (New York: Cambridge University Press, 1992), 123-147; Sergei Zhuk, 'Religion, 'Westernization,' and Youth in the 'Closed City' of Soviet Ukraine, 1964-84," The Russian Review, 67, 4 (Oct. 2008); S. Frederick Starr, Red and Hot: The Fate of Jazz in the Soviet Union, 1917-1980 (New York: Oxford University Press, 1983), 261-288.

28. For how Soviet youth imagined these regions, see Alexei Yurchak, Everything Was Forever, Until It Was no More: The Last Soviet Generation (Princeton: Princeton University Press, 2006), 158-206.

29. Artemy Troitsky, Back in the USSR: The True Story of Rock in Russia (Winchester: Faber and Faber, 1988), 14. For other eyewitness accounts, see, for example, Kozlov, "Kozel na sakse..."; V.P.Aksenov, V poiskakh grustnogo bebi: kniga ob Amerike [In search of a melancholy baby: A book about America] (New York: Liberty Publishing House, 1987); V.I. Slavkin, Pamiatnik neizvestnomu stiliage [Memorial to the unknown stiliaga] (M.: "Artist. Rezhiser. Teatr,' 1996).

30. Most notably in the notorious article "Stiliaga" by D. Beliaev in the satirical paper Krokodil, March 10, 1949. 
other youths labeled as delinquents, particularly at a time of rising international tensions. Greatly exaggerating the menace posed by the so-called deviants to their purportedly timeless moral communities and middle-class family values, countries across Europe and North America fell into moral panics ${ }^{31}$ and responded, for the most part, with governmental coercion to manage the assumed peril. ${ }^{32}$

Party policy toward fashioning "ideal" communist citizens experienced substantive transformations throughout the existence of the Soviet Union, yet constantly mirrored the broader trends of its time. During the NEP, the authorities tended to rely on the educational system to forge young New Soviet People ${ }^{33}$ and, blaming deviance on the revolutionary transformations in the country, generally offered social instruction ${ }^{34}$ and political disciplining ${ }^{35}$ as the cure. The Stalinist state put more emphasis on promoting labor and collectivism to construct model communists and rehabilitate misbehaving citizens, ${ }^{36}$ and adopted a harsher approach to dealing with purported deviance characterized by forceful state interventions. ${ }^{37}$ Still, the postwar Stalin leadership expressed few concerns with either young hooligans or stiliagi, perhaps due to the demands of postwar reconstruction. Though some criticism of "westernized" youth in newspapers did appear with the launch of the anti-cosmopolitanism campaign, research shows that it may well have reached its apogee in 1949 with Beliaev's article. ${ }^{38}$ An

31. For "moral panics," see Stanley Cohen, Folk Devils and Moral Panics: The Creation of the Mods and Rockers (New York: Basil Blackwell, 1987).

32. Among others, see Uta G. Poiger, Jazz, Rock, and Rebels: Cold War Politics and American Culture in a Divided Germany (Berkeley: University of California Press, 2000); James Gilbert, A Cycle of Outrage: America's Reaction to the Juvenile Delinquent in the 1950s (New York: Oxford University Press, 1986); Steven Mintz, Huck's Raft: A History of American Childhood (Cambridge: Harvard University Press, 2004), 275-309; John Springhall, Coming of Age: Adolescence in Britain, 1860-1960 (Dublin: Gill and Macmillan Ltd, 1986); John R. Gillis, Youth and History: Tradition and Change in European Age Relations, 1770-Present (New York: Academic Press Inc., 1981), 132-210.

33. Halfin, From Darkness..., 205-282.

34. Konecny, Builders and Deserters...,232-234.

35. Disagreement existed between various groups within the administration in the mid-1920s over the best course of action in dealing with "deviant" youth; while some wanted to offer engaging leisure, many others demanded an escalation of political propaganda. In part due to this disagreement and other pressing concerns, little was done in offering interesting leisure during the NEP, especially since those advocating political disciplining triumphed by 1928 : Gorsuch, Youth, 116-138.

36. Sheila Fitzpatrick, Everyday Stalinism: Ordinary Life in Extraordinary Times: Soviet Russia in the 1930s (New York: Oxford University Press, 1999), 75-79, and Stephen Kotkin, Magnetic Mountain: Stalinism as a Civilization (Berkeley: University of California Press, 1995), 157-197.

37. Peter H. Juviler, "Contradictions of Revolution: Juvenile Crime and Rehabilitation," in Abbott Gleason, Peter Kenez, and Richard Stites, eds., Bolshevik Culture (Bloomington: Indiana University Press, 1985), 261-278, and Konecny, Builders and Deserters..., 235-236.

38. The Stalinist Komsomol did take some limited actions against stiliagi, reprimanding them and expelling a handful from its ranks: see Edele, "Strange Young Men..." and Fürst, "The Importance..." For the anti-cosmopolitanism campaign against Jewish and foreign influence, see Zubkova, Russia After the War..., 1-51, and Vakser, Leningrad poslevoennyi..., 410-433. 
investigation of $M K$ and $K P$ from 1950 to Stalin's death shows almost no coverage of hooligans and stiliagi in either, while almost immediately afterwards, many stories criticizing such young people appeared. ${ }^{39}$

In an apparent continuity with the Stalinist approach to rehabilitating individuals and making the New Soviet Person via labor, the post-Stalin Party implemented the 1953 Khrushchev-backed Virgin Lands campaign to have youth exploit previously unfarmed lands. Nonetheless, the state judged such policies as inadequate, ${ }^{40}$ and launched the leisure initiative in 1954-1955, the years Khrushchev assumed power. The resolutions of the February 1954 Twelfth Komsomol Congress, the first after Stalin's death, harshly condemned "immoral behavior in everyday life." ${ }^{11}$ The KCC quickly escalated and broadened the campaign with a more expansive reprimand of "amoral behavior," including both hooliganism and stiliazhnichestvo, with the August 1955 closed letter. This multifaceted initiative set the goal of displacing the supposedly deviant leisure of hooligans and stiliagi with "rational," i.e., planned, conscious, and modern, leisure, ${ }^{42}$ in order to forge model communist citizens. ${ }^{43}$ The campaign, part of a broader movement aimed at forging a truly communist everyday life during the Thaw, ${ }^{44}$ harkened back to the emphasis on social instruction and political discipline of the NEP; nevertheless, it proved unprecedented in the scope, magnitude, cohesiveness, and continuity of the state's attention to "deviant" leisure behavior. This policy also reflected the increase in the mid-1950s of the amount of free time due to a shorter work week for all workers, especially young ones, and the increasingly widespread access to higher education. ${ }^{45}$ The first phase of the initiative,

39. For example, I found no use of the term stiliaga in $M K$ from 1950 to Stalin's death, but it appears almost immediately afterwards: April 23, 1953, article "Stiliaga."

40. KP was even criticized in 1956 for its excessive emphasis on developing love for labor, and insufficient attention to the "moral upbringing" of youth: RGASPI, f. M-1, op. 32, d. 821, 1. 5051 .

41. RGANI (Rossiiskii gosudarstvennyi arkhiv noveishei istorii), f. 5, PCC, op. 30, General Department d. 38,1. 10 .

42. For "rational leisure (razumnyi otdykh)", see, for example, RGASPI, f. M-1, op. 3, d. 830, 1. 4-5.

43. For more on leisure in this period, see John Bushnell, "Urban Leisure Culture in Post-Stalin Russia: Stability as a Social Problem?," in Terry L. Thompson and Richard Sheldon, eds., Soviet Society and Culture: Essays in Honor of Vera S. Dunham (Boulder: Westview Press, 1988), 58-86, and N.B. Lebina and A.N. Chistikov, Obyvatel'i reformy: kartiny povsednevnoi zhizni gorozhan $v$ gody népa $i$ khrushchevskogo desiatiletiia [Ordinary citizens in a time of reform: Images of the everyday life of urbanites during the NEP years and the Khrushchev decade] (SPb.: Dmitrii Bulanin, 2003). For the role of leisure in shaping beliefs, see James F. Murphy, Concepts of Leisure: Philosophical Implications (Englewood Cliffs: Prentice-Hall, Inc., 1974), 1-13.

44. For example, see Miriam Dobson, "Show the Bandit-Enemies no Mercy!': Amnesty, Criminality, and Public Response in 1953," in Jones, ed., The Dilemmas..., 21-40, and Christine Varga-Harris, "Forging Citizenship on the Home Front: Reviving the Socialist Contract and Constructing Soviet Identity During the Thaw," ibid., 101-116.

45. A $1955 \mathrm{KCC}$ decree specifically limited the work day of young people to four hours for those aged 14-16, and seven for 16-18: RGASPI, f. M-1, op. 3, d. 877, 1. 3-4. For a report on how students at technical colleges had plenty of free time, ibid., op. 32, d. 802,1. 125. 
characterized by a relatively consistent press rhetoric, lasted from 1954 to 1961 . The autumn of 1961 witnessed the ratcheting of the drive to achieve communism, embodied in the Twenty-second Communist Party Congress's promise to achieve communism by 1980, the introduction of the Third Party Program, and the embrace of the "Moral Code of the Builder of Communism."46 As a constituent part of this thrust, the KCC re-energized the leisure campaign with another closed letter in 1962 on the need to control and guide youth leisure behavior. ${ }^{47}$

\section{The press as a signaling mechanism}

Newspapers had the essential function of "signaling," or passing information from the center to local Komsomol organizations about the appropriate methods of controlling free time. ${ }^{48}$ In regard to the leisure initiative, the KCC decreed in 1954 that "Komsomol newspapers and journals... depict praiseworthy examples of educational (vospitatel'naia) work among youth", a directive which encouraged the publication of accounts of well-functioning free time management. ${ }^{49}$ As a case in point, a 1956 MK article catalogs the "Rights and Responsibilities" of youth bases, organizations that served to monitor leisure. This list includes goals such as the "struggle against alcoholism, hooliganism," achieved through "talking with those who disturb public order." ${ }^{50}$ In effect, such newspaper stories demonstrated how to use the symbolic violence of public opprobrium to ensure model behavior. Another article depicts hooligans starting fights in the club of a construction workers' dormitory. The Komsomol committee decided to close the club instead of confronting them, and the journalist condemned local Komsomol members for "retreating before hooligans." 51 Such strongly worded public criticisms endeavored to push Komsomol youth to mobilize together against juvenile delinquency.

The press spent much ink promoting an innovative Khrushchev-era institution, Komsomol patrols, which used both symbolic and physical violence for the imposition of social control; 52 it has been argued that such patrols served to

46. For the Third Party Program's sentiments toward youth, see Programma Kommunisticheskoi partii Sovetskogo Soiuza [The Program of the Communist party of the Soviet Union] (M.: Politizdat, 1967), 107-108, 116-125. On the Moral Code, see Deborah A. Field, Communist Morality and Meanings of Private Life in Post-Stalinist Russia, 19531964 (Ph.D. dissertation, University of Michigan, 1996), 28-33.

47. RGASPI f. M-1, op. 32, d. 1101,1. 3-33.

48. For signaling, see Terry Martin, The Affirmative Action Empire: Nations and Nationalism in the Soviet Union, 1923-1939 (Ithaca: Cornell University Press, 2001), 22-23.

49. RGASPI, f. M-1, op. 3, d. 830,1. 4-5.

50. "Prava i obiazannosti" [Rights and responsibilities], $M K$, February 1, 1956. For articles with similar themes, see $K P$, June 5, 1955; $M K$, May 31, 1956; KP, September 13, 1956.

51. "Gde molodezhi otdykhat'?" [Where can young people relax?], KP, June 22, 1955. For parallel cases, see MK, March 9, 1957; MK, March 12, 1958 ; KP, January 9, 1957.

52. For policing under Khrushchev in general, see Louise I. Shelley, Policing Soviet Society: The Evolution of State Control (New York: Routledge, 1996), 44-45. 
discipline their participants into official collectives. ${ }^{53}$ Newspapers endeavored to model ideal patrols, as in, for example, a published letter praising a group that "gladly helps the residents of our neighborhood," taking care of problems ranging from hooliganism to traffic violations. ${ }^{54}$ By depicting local residents as enthusiastically accepting the help of the patrol, these newspaper accounts sought to validate these new institutions among the population. Another story describes how six young hooligans invaded a youth club dance and started a fight with the patrol members guarding the party. The patrol, ready for trouble, beat back the hooligans, and "now [young people] can dance in this youth club as much as [they] want."55 These tales intended to legitimize the violence of the patrols, and encouraged the young to show initiative in organizing patrols by positioning the latter as boldly defending citizens against hooligans.

While such eulogistic accounts continued in the later Khrushchev years, the period also witnessed the spread of more ambiguous opinions of Komsomol oversight of free time. In one instance, $M K$ reports on a 1963 conference of patrol members who, while finding much to praise, also admitted that "often, we are not choosy about whom we accept into the patrols."56 An even more critical 1964 article censured Komsomol activist Gurman Malov in the Frunzensk district for accepting a young man named Vladimir Sokolov into the Komsomol while the police investigated the latter for hooligan behavior. The journalist regarded such a formalistic approach as "the same type of obfuscation as falsely increasing industrial production numbers." 57 Meant to shame Komsomol officials into improving the imposition of social control, those stories also illustrate the problems inherent in the attempts to implement the leisure campaign in the Soviet context.

\section{Hooligans and stiliagi in the Komsomol press}

The Thaw-era Komsomol press took a more active role in enforcing ideologically appropriate conduct by directly condemning youth misbehavior. The rapid escalation in the harshness and frequency of censorious accounts from 1954 reflected the KCC's anti-hooliganism decree, which stated that "Komsomol

53. In particular by Juliane Fürst, who sees the Khrushchev regime as dealing with hooligans and stiliagi primarily via the innovative coercive mass mobilization measures of the $1950 \mathrm{~s}$, and also the more traditional production-oriented initiatives such as the Virgin Lands campaign: see her "The Arrival of Spring?..."

54. "Liudi s krasnoi poviazkoi" [People with a red armband], MK, May 21, 1961. For comparable accounts, see $M K$, May 23, 1959; MK, May 24, 1961; MK, May 9, 1959.

55. "Streliat' ne obiazatel'no" [Shooting is not necessary], MK, July 13, 1961. See also KP, January 28, 1955; MK, July 22, 1961; KP, June 7, 1958.

56. "Ne vroz', a vmeste" [Not apart, but together], MK, April 24, 1963. Mitrokhin also talks about problems with Komsomol patrols in his Russkaia partiia.

57. "Neveroiatnaia istoriia" [An incredible story], KP, February 8, 1964. For parallel criticisms, see KP, June 24, 1964; KP, June 22, 1962; MK, September 4, 1962. 
newspapers must brand with shame specific carriers of evil" such as hooligans. ${ }^{58}$ This pattern appeared to hold true in the provinces: a 1956 document described how the Komsomol press in Rostov on Don sharply criticized "unworthy" behavior, and Saratov factory newspapers reprimanded hooligans and drunks. ${ }^{59}$ The strident tone of the newspapers underscores the fact that the symbolic violence of public censure became the government's main coercive tool after it forswore the extensive use of direct state force and decided to rely on infrastructural power - a notable shift from the later Stalin years.

The Komsomol press frequently condemned violent, hooligan young males. A typical story tells of four drunken young men who went to a backyard dance. Returning home, they accosted a well-dressed woman, demanded money, and stabbed her. ${ }^{60}$ This account sought to illustrate that immoral leisure, particularly accompanied by alcohol, inevitably led to violent hooligan conduct. ${ }^{61}$ Newspapers widely used the discursive technique of naming and shaming hooligans, such as the worker Sergei Semii, who "almost knocked out the teeth of some, and cursed others." 62 Sergei, sentenced to fifteen days of jail under the new 1956 law on petty hooliganism for his conduct, which might previously have brought only a warning from the police, served as a didactic case for the redefinition of behavior; this example fits in with recent findings which posit that the 1956 law functioned to actually create hooligans by labeling previously marginal conduct hooliganism. ${ }^{63}$ The youth press employed the discursive strategy of inviting readers to respond to published letters on delinquent free-time conduct, a tactic used in the late Stalin era against denigrated groups such as "cosmopolitans," but not in matters relating to the everyday free-time behavior of regular Soviet citizens. Tasia Gorshkova's 1955 letter about how Sergeev hit her because she refused to dance with him, with no one else around defending her, brought numerous responses ${ }^{64}$ The many letters printed by $K P$, which appeared in several articles over the period of a few months,

58. RGASPI, f. M-1, op. 3, d. 830,1. 4-5.

59. Idem, op. 32, d. 813,1. 8, 23.

60. "Iurii Vikulov i drugie" [Iurii Vikulov and others], $M K$, March 13, 1957. For other articles on hooliganism, see KP, June 7, 1955; MK, March 14, 1957; KP, March 2, 1958.

61. Alcoholism, depicted as intertwined with hooliganism, constituted a perennial problem for the Soviet state: Walter D. Connor, Deviance in Soviet Society: Crime, Delinquency, and Alcoholism (New York: Columbia University Press, 1969), 34-79. The Khrushchev state initiated a propaganda offensive against alcoholism in July 1954 with a decree by the PCC: see the document collection N.V. Trushchenko and B.I. Myshenkov, eds., Naslednikam revoliutsii: Dokumenty partii o komsomole $i$ molodezhi [The heirs of the revolution: Documents of the Party about the Komsomol and youth] (M.: "Molodaia Gvardiia," 1969), 394-398

62. "Bravyi paren"" [A brave guy], $M K$, October 3, 1957. For other instances of shaming, see MK, May 30, 1957; KP, June 9, 1955; KP, July 9, 1958.

63. See Brian LaPierre, in "Making Hooliganism on a Mass Scale: The Campaign against Petty Hooliganism in the Soviet Union, 1956-1964," Cahiers du Monde russe, 47, 1-2 (2006): 1-28.

64. "Ia dumaiu, chto oni trusy" [I think they are cowards], KP, May 19, 1955. For articles making analogous points, see $M K$, July 18, 1961; MK, January 25, 1961. 
overwhelmingly condemned Sergeev, advocating the creation of an atmosphere of intolerance for such behavior, and called those who stood by "just cowards." 65 The publication of numerous responses to Tasia's letter indicates the intention of the press to convince young newspaper readers that they, like their peers, who supposedly sent the letters, should publicly express their contempt for alleged deviants and thus willingly participate in the state's project of constructing activist citizens. In the later Khrushchev era, the anti-hooligan newspaper discourse became noticeably harsher. A 1962 KP account exemplified this attitude, describing a hooligan, Aleksei Ivanov, who beat up his wife and children. Drawing on and inverting the communist ideological trope that "we need to struggle for each human being," the author stated that indeed, "we need to struggle for human beings - the ones whose lives Aleksei Ivanov poisons."66 Such unforgiving indictments paralleled, and served to justify, the escalating number of court sentences imposed for violent hooliganism in the post-1961 years. ${ }^{67}$

Stiliagi represented the other main category of "deviants" targeted by the 19541955 initiative. In a prototypical story, a letter published in 1955 condemned a student, Ionas, for leading a "double life." A seemingly normal student during the day, he spent evenings in restaurants with the "wrong crowd." His roommates covered up for him and, according to the letter, deserved criticism along with Ionas for not informing on him. ${ }^{68}$ Local newspapers mirrored this rhetoric, as exemplified by a January 1956 article in a Leningrad college paper that condemned home-made rock records, and unequivocally stated that "those who spread this trash should be punished."69 This account, submitted and signed by Komsomol patrol members, served as a warning to stiliagi, thus combining symbolic violence with the threat of real violence. Newspapers also brought reproach on female stiliagi, as in a published missive from a group of young women ashamed of their friend, Valia. According to this denunciation, Valia danced differently (meaning in a "western" fashion) from her peers, wore excessive makeup, and showed too much of her body, while working poorly and not participating in collective leisure. ${ }^{70}$ The publication of a multitude of responses condemning Valia patently illustrates the intention of the press to convince publicly engaged young people that all worthy

65. "Tovarishchi tozhe vinovny" [The comrades are also guilty], $K P$, June 8, 1955 and continued in $K P$, August 4, 1955.

66. $K P$, November 10, 1962. For other articles, see $K P$, September 8,$1961 ; K P$, September 11 , 1964; KP, June 9, 1964.

67. Harold J. Berman, Justice in the USSR: An Interpretation of Soviet Law (Cambridge: Harvard University Press, 1966), 84-86.

68. "Ne tot drug, kto potakaet" [A lenient friend is no friend], $K P$, June 2, 1955. For articles making similar points, see $M K$, March 10, 1957; MK, March 13, 1957; KP, August 9, 1958.

69. V.E. Ronkin, Na smenu dekabriam prikhodiat ianvari: vospominaniia byvshego brigadmil'tsa i podpol'shchika, a pozzhe - politzakliuchennogo i dissidenta [Januaries replace Decembers: Remembrances of a former volunteer militia member and underground revolutionary, and later - a political prisoner and dissident] (M.: Obshchestvo "Memorial" Izd-vo "Zven'ia", 2003), 73.

70. "Nam stydno za podrugu" [We are ashamed of our girlfriend], KP, June 21, 1955. 
citizens needed to participate in the collective censure of misbehaving young women. ${ }^{71}$ Following the 1957 International Youth Festival in Moscow, which brought a substantial opening to "western" popular culture, and particularly the reenergized drive for communism of the Twenty-second Congress, newspapers intensified their censure of stiliagi. A representative article depicts a young man, Gennadii Baranov, who dressed in a "western" style and had the nickname "Bambino," on trial for illegal trade in foreign clothing and currency. Drawing on the language of the 1961 initiative against parasites and tuneiadtsy ("lazybodies"), which explicitly conflated stiliagi with parasites, the author writes that "we should not let tuneiadtsy ruin our lives, especially now, when we are building communism." 72 This story utilized the discursive technique of drawing a clear line between "western"-oriented young people and the rest of the youth, reconfiguring the boundaries of inclusion and exclusion with the goal of putting stiliagi outside the pale of Soviet society:73 still, some scholarship suggests that publicizing such behaviors led to their emulation by others. ${ }^{74}$

Recent literature suggests that the Stalinist government decided that society had achieved socialism by the mid-1930s, and official discourse from that point defined "proper" citizens as those who worked hard, expressed loyalty to the Party's vision, and had the right class background ${ }^{75}$ Though Stalinist authorities still demanded exemplary free-time conduct of the new "cultured" managerial and communist elite, ${ }^{76}$ they paid less attention to the leisure of the rest of the populace, exemplified by the comparatively sluggish response of the postwar state to youth hooliganism and birth of stiliazhnichestvo. In a shift from postwar Stalinist ideology and practice, Khrushchev embarked on a renewed drive to achieve communism that recalled the pattern of the Cultural Revolution, where the Party leadership imposed the morals previously required of Party members to the whole population. ${ }^{77}$ Consequently, in contrast to the situation during the late Stalin period, the Khrushchev leadership considered model leisure behavior necessary for all, and

71. For the responses, see KP, August 11, 1955, "Net, eto nashe delo" [No, this is our business].

72. "Kakimi oni vernutsia?" [Who will they return as?], MK, May 22, 1962. Indeed, the state instituted the death penalty for large-scale foreign currency speculation in 1961, illustrating its intentions to expunge "western"-oriented illegal practices: Berman, Justice..., 84-86. For other articles castigating style-seekers, see $M K$, March 14, 1964; KP, January 21, 1962. For the antiparasite campaign, see Fitzpatrick, "Social Parasites..."

73. William J. Risch makes the argument that just such repression in the 1970 s enabled Soviet hippies to create an alternative identity, in "Soviet 'Flower Children'. Hippies and the Youth Counter-Culture in 1970s L'viv," Journal of Contemporary History, 40, 3 (Jul. 2005): 565-84.

74. Fürst, "The Arrival of Spring?..."

75. David Hoffman, "Was there a 'Great Retreat' from Soviet Socialism? Stalinist Culture Reconsidered," Kritika: Explorations in Russian and Eurasian History, 5,4 (Fall 2004), 651674.

76. Enforced by the Party control commission: David Hoffman, Stalinist Values: The Cultural Norms of Soviet Modernity 1917-1941 (Ithaca: Cornell University Press, 2003), 57-88.

77. Michael David-Fox, "What is Cultural Revolution?," The Russian Review, 58, 2 (Apr. 1999): 181-201. 
thus perceived hooligans and stiliagi as fundamental obstacles to creating a communist utopia. Intriguingly, hooligans and stiliagi may even have proved functional for the Thaw-era Party by enabling the press to demonstrate how not to behave, thereby clarifying the standards for the rest of the youth. ${ }^{78}$

The evolving rhetoric of the leisure campaign illustrates the transformation in the press of the concept of citizenship. Working hard, expressing loyalty, and receiving Stalin's gifts, which were the attributes of "good" Soviet people according to late Stalinist newspapers, no longer sufficed. Evidence indicates that the Khrushchev party insisted that young people become publicly active citizens engaging in harsh condemnation of those involved in ideologically prohibited leisure. The Stalin government called on Soviet citizens to denounce unlawful conduct, ${ }^{79}$ but in contrast to the Khrushchev leadership, expressed little concern with "deviant" youth leisure. During the Thaw, however, these so-called deviants were deemed to merit censure, humiliation, and exclusion from society, and people failing to denounce them were deemed to warrant considerable punishment as well: according to a pamphlet from the official press of the judiciary, individuals who knew about inappropriate activities but did not inform the authorities effectively assisted the continuing perpetration of such acts, and thus deserved "harsh moral reprimand from society." 80 This rhetoric intensified after the Twenty-second Congress heightened the drive to build communism, which resulted in escalating frustration over the failure to expunge juvenile delinquency using the purportedly correct methods of the Khrushchev era. This discursive reinterpretation of the concept of model communist citizenship constituted an essential component of the state's attempt to construct communism through infrastructural power by mobilizing society and employing the symbolic violence of public criticism.

\section{Ambiguous discourses, unexpected consequences}

While many publicly engaged young people had no problems internalizing the Party's precepts, others had more difficulty, since the values ascribed to the New Soviet Person in the press proved somewhat contradictory when realized in everyday life. The uncertainties involved in identifying those who deserved exclusion from the boundaries of society constituted a source of ambiguity that undermined the cohesion of public discourse. A letter to $M K$ on the nature of

78. This point is informed by the functional theory of deviance, which sees deviance as socially useful in clarifying the limits of acceptability: Emile Durkheim, The Rules of the Sociological Method, (New York: The Free Press, 1965), 47-75.

79. Sheila Fitzpatrick, "Supplicants and Citizens: Public Letter-Writing in Soviet Russia in the 1930s," Slavic Review, 55, 1 (1996): 78-105. Notably, the Khrushchev regime also called for denunciation of crimes, especially by Soviet officials: Gleb Tsipursky, “'As a Citizen, I Cannot Ignore These Facts': Whistleblowing in the Khrushchev Era," Jahrbücher für Geschichte Osteuropas, 58, 1 (2010), forthcoming.

80. A.N. Kosarevich, Sovetskaia obshchestvennost' $v$ bor'be s prestupnost iu [Soviet society and its struggle with crime] (M.: Gosiurizdat, 1959), 20. 
beauty that raised the vital issue of personal appearance, which was key in identifying stiliagi, elicited widely varied published responses. Some letter-writers considered that "humility is a person's most beautiful aspect," while others argued that "wearing fashionable, tasteful clothing" is fully compatible with humility. Another set of opinions deemed both "people wearing ultrafashionable and oldfashioned clothing equally ridiculous," and called for holding to the golden mean. The conclusion of the story did not provide clarification, with the author of the article defining the nature of beauty as "harmony." 81 In a time when wearing jeans and "too much" make-up could result in public criticism, when the question of whether one could be fashionable and still remain a "moral" communist weighed heavily on young people's minds, the message of "harmony" most likely proved distinctly unhelpful. Such stories in youth newspapers distantly echoed broader debates among Soviet fashion workers and in the pages of specialized magazines on appropriate styles which frequently argued over the appropriateness of "western" models. ${ }^{82}$ The lack of unity in the discourse, both among professionals and in youth newspapers, resulted in confusion over the definition of the full parameters of "correct" appearance and conduct. Considerable scope existed for individual interpretation, and the process of searching for the "right" way to appear, behave, and live strengthened the impulse toward the formation of an autonomous identity among the Thaw generation. 83

Still, the discursive ambiguity may have functioned as a deliberate political technique of the Khrushchev Party. Consider the following letter, apparently from an ordinary young woman, printed prominently on the front page of $M K$ :

Lately, many young women have begun to wear pants. Yet this clothing surprises some passersby, and occasionally one hears "stiliaga" addressed to those women. I think pants are comfortable clothes for industrial work, for housework, and, of course, for sports. If pants are convenient for working with machinery, skating, hiking, and cleaning, then you should wear them, and pay

81. "V chem krasota cheloveka?" [Wherein lies a person's beauty?], MK, May 27, 1961. For other stories on fashion, see $M K$, August 4, 1957; KP, February 13, 1956; MK, March 9, 1958.

82. For such debates, see S.V. Zhuravlev and Jukka Gronnow, "Krasota pod kontrolem gosudarstva: osobennosti i etapy stanovleniia sovetskoi mody" [Government control over beauty: The specifics and stages of the development of Soviet fashion], The Soviet and PostSoviet Review, 32.1 (2005), 1-92; Olga Gurova, "The Art of Dressing. Body, Gender and Discourse on Fashion in Soviet Russia in the 1950s and 60s," in Eugenia Paulicelli and Hazel Clark, eds., The Fabric of Cultures: Fashion, Identity, Globalization (New York: Berg, forthcoming); L.V. Zakharova, "Naibolee raspostranennoi iavliaetsia forma priamogo pal'to s odnoborotnoi zastezhkoi': o sovetskoi mode epokhi 'ottepeli'" [The most widespread style is a straight coat with a clasp at the back: Soviet fashion in the 'Thaw' era], Neprikosnovennyi zapas: Debaty o politike i kul'ture, 45, 1 (2006) [http://magazines.russ.ru/ $\mathrm{nz} / 2006 / 1 / \mathrm{za} 24 . \mathrm{html}]$

83. Anna Krylova argues that the ambiguity in the 1930s discourse on youth left space for them to search for an independent identity, in "Identity, Agency, and the First Soviet Generation" in Stephen Lovell, ed., Generations in 20th Century Europe (New York: Palgrave Macmillan, 2007), 101-122. My research shows that in the 1950s, the official rhetoric's ambiguity combined with its encouragement of youth initiative did not only enable, but impel youth to develop an independent identity. 
no attention to those who, because of their rigid and conservative mindset (kosnost ${ }^{\mathcal{}}$ ), call this piece of clothing stiliaga-like. ${ }^{84}$

I suggest that the newspaper's publication of this missive, in parallel with the broader discussions on this subject, emblematizes a deliberate opening of negotiating room on the definition of stiliagi - implying that working hard and participating in officially organized leisure mattered quite a bit more than "western"-influenced gender-bending clothing. ${ }^{85}$ The appearance of the letter on the first page draws attention to the Komsomol's willingness to give young people a measure of individual self-expression in the question of fashion and taste, in contrast to the restrictive stance of "rigid and conservative" members of the older generation. ${ }^{86}$ This indicates that the state may have consciously extended a compromise to the multitude tempted by some aspects of "western" culture yet faithful to communist ideology at heart, inviting them to become "proper" citizens while allowing them to maintain a degree of non-conformism. ${ }^{87}$ At variance with the tendencies of the postwar Stalin years to totalizing exclusion, such as of "enemy nations," this novel Khrushchev-era approach endeavored to excise only the minority of full-fledged hooligans and stiliagi who could not be saved - for example, Sergeev and Bambino.

Consequently, in addition to the binary ideal types of "builders" of communism and the "deserters" from this task characteristic of the official rhetoric of the NEP and especially Stalin years, ${ }^{88}$ the evidence indicates that the press language of the Thaw opened up some room for the public tolerance of amorphous, complex, variegated youth lifestyles. ${ }^{89}$ This shift is perhaps best visible in the rhetoric on semi-marginal "problem" (trudnye) youths, depicted as those who committed minor "antisocial" acts including cursing, shoplifting, or cutting school, yet who nevertheless could, and should, be redeemed. As one 1964 MK editorial, entitled "The Fate of a 'Problem' Youth," states, "They cannot be discounted. We need to think, collectively, about how to discipline them, turn them into people useful for our society." 90 Such sentiments characterized the pre-1961 period as well, as

84. "A kak dumaete vy?" [What do you think?], MK, March 10, 1957. For other articles in which letters from readers provide a conflicting definition of stiliagi, see $M K$, March 13, 1957; KP, July 9, 1958; KP, August 6, 1958.

85. Wearing pants was considered indecent for women even in the late 1970s : Kelly, Children's World..., 578.

86. For the role of taste in shaping identity, see Pierre Bourdieu, Distinction: A Social Critique of the Judgment of Taste (Cambridge: Harvard University Press, 1984), 466-484.

87. Yurchak has thoughtfully identified such an ambiguous approach to what he calls the "Imaginary West," characterized by a tension between the ideals of "bad" cosmopolitanism and "good" internationalism, for example in the treatment of Pablo Picasso: see his Everything was Forever, 164-165. My research suggests that other important Soviet ideals, such as being a hard laborer, could also redeem "western"-influenced individuals.

88. Konecny, Builders..., 10 .

89. For an intriguing parallel shift in Britain from the early to the late 1950s, see Gillis, Youth..., 132-210 
exemplified by a story from the late 1950s relating how a youth, Alexander Grachev, fell into a bad crowd and began to behave rudely, lie, and steal. While Grachev's friends stood by him and tried to "return him to the right path," the teachers in Grachev's school failed to support this endeavor, "and attempted to attach the label of 'thief' and 'hooligan' to him," for which they received due censure. ${ }^{91}$ Another case in point is that of a former Komsomol member, now a retired adult, who mentored such "problem" youths. Written from the perspective of the adult, the article describes how a young individual who behaved badly and "turned off the right path," received sage instruction and oversight from the former Komsomol member, and slowly improved, finally joining the Komsomol. The story asks, "Why should every one of us not mentor at least one 'problem' youth?"92 Officials similarly encouraged mentoring, with the first secretary of the Moscow city Komsomol stating in February 1964 that "our goal is for every 'problem' youth to have a real comrade, a Komsomol member as mentor," and dolefully noting that only 2,500 Komsomol members actively engaged in mentoring. ${ }^{93}$ Those accounts directed all citizens, and particularly Komsomol members, to help rehabilitate "problem" youths, while implicitly tolerating those non-conformists who had not yet received appropriate mentorship.

The best, most in-depth portrait of such a "problem" youth exists in a popular 1961 novel, Ticket to the Stars (Zvezdnyi bilet), by a daring, controversial young author, Vasilii Aksenov. Empowered by the spirit of the Thaw, he and other writers endeavored to expand the limitations imposed by Socialist Realism and deal with the realities and vital problems of young people's lives. ${ }^{94}$ In the novel's first scene, the protagonist, seventeen-year-old Dimka Denisov, runs across the street on a red signal, leading his older brother to comment that "he simply runs wherever he wants. He does not notice any signals." Wearing jeans, interested in girls, jazz, and dancing, and dismissive of Komsomol meetings and public life, Dimka lacks a long-term life goal, and condemns his brother's conformism to a life determined by his parents. At the same time, Dimka hates corruption and illegal speculation in "western" goods, and ends the book working as a sailor at a fishing kolkhoz - to all outward appearances a prototypical heroic proletarian. The key questions of Aksenov's narrative, asked of Dimka by his brother and girlfriend, and then by

90. "Sud'ba 'trudnogo' podrostka" [The fate of a 'problem' youth], MK, March 3, 1964. For other articles on "problem" youth, see KP, February 16, 1960, and KP, September 5, 1961. For a July 1963 KCC resolution praising oversight of these youths, see Sbornik postanovlenii TsK VLKSM (ianvar'-dekabr' 1963 goda) [Collection of decrees by the KCC (January-December 1963)] (M.: "Molodaia gvardiia”, 1964), 277-281.

91. "Delo Aleksandra Gracheva" [The case of Aleksandr Grachev], MK, January 21, 1958. For a similar story of pedagogical errors, see $K P$, September 5, 1961 .

92. “A byl on 'trudnym' paren'kom”[He was a 'problem' youth], KP, February 16, 1960. For other articles on mentoring, see $M K$, December 16, 1959; $M K$, July 9, 1963; KP, June 10, 1962.

93. TsAOPIM (Tsentral'nyi arkhiv obshchestvenno-politicheskoi istorii Moskvy), f.635, Moscow Komsomol city committee, op. 15, 1962-66, d. 188, 1. 52.

94. Deming Brown, Soviet Russian Literature since Stalin (New York: Cambridge University Press, 1978), 180-217. 
Dimka of himself, are, "What do I want?... What am I living for?" The novel ends inconclusively, with Dimka commenting ironically about himself as "a sad example of delayed development. A good topic for a Komsomol meeting."95 The writings of Aksenov and other reformist authors sought to speak to and simultaneously reflected the tortuous search for identity of contemporary youth, many of whom combined the seemingly contradictory values ascribed by the Komsomol press to the New Soviet Person and to a stiliaga; research based on interviews with former Soviet citizens has led to similar conclusions.96 Concomitantly, reformist youth literature opened up increasingly more space for young people to engage in non-conformist leisure behavior and adopt a nonconformist personal appearance via the portrayal of figures like Dimka as positive, if problematic, protagonists.

Hard-line functionaries frequently disparaged such soft, tolerant attitudes. A 1962 note from the KCC to the PCC (Party Central Committee) on the struggle with young people's "amoral behavior," including hooliganism and stiliazhnichestvo, attributes, especially the latter, to increased propaganda by capitalist states which, according to the document, infected Soviet youth with the same problems as found in the young generation of western Europe and America. The KCC reprimanded writers such as Aksenov for, under the cover of working against the cult of personality and claiming to speak about "real life," contributing to the growth of amorality, vulgarity, and licentiousness among young people..$^{97}$ Another document, this time a 1957 internal report from the PCC's Agitprop department, censured youth newspapers, including $M K$, for their inadequate struggle against "bourgeois ideology" and excessive offerings of "light, entertaining material."98 These disparaging statements in high-up Party discussions mirrored wide-ranging confrontations between what scholars called the "friends and foes of change" 99 within the Khrushchev era Communist Party, the extent to which the USSR should open up to "western" influence being one of the most important subjects of debate. Though many officials certainly wished to retreat to postwar Stalin era hard-line positions, the fact that the media continued to publish materials reflecting tolerant, soft-line approaches indicates widespread support among the officialdom, and especially at the top, for deliberately providing young people with negotiating room. Also, during shifts that brought a harsher rhetoric against "western" influence, such as following the 1957 Festival and the Twenty-second Congress, the existence of past discursive ambiguities may have, to paraphrase a recent work,

95. V.P. Aksenov, Sobranie sochinenii [Collected works] (M.: Izdatelskii Dom "Iunost", 1994), 183-332.

96. Described in Yurchak, Everything..., for example 200-202.

97. For a 1962 report by the Komsomol Central Committee that accused Aksenov and other reformist authors of vulgarity, see RGASPI, f. M-1, op. 32, d. 1101,1. 49.

98. RGANI, f. 5, op. 34, Agitprop department, d. 17, 1. 41-43.

99. Stephen F. Cohen, "The Friends and Foes of Change: Reformism and Conservatism in the Soviet Union," in Cohen, Rabinowitch and Sharlet, eds., The Soviet Union, 11-31. 
allowed young people to consider themselves good Soviet citizens while disagreeing with official rhetoric. ${ }^{100}$ Overall, newspaper articles continued both to inspire and to contribute to public debates over what constituted appropriate behavior, clothing, and values - and what society should set outside the boundaries of acceptability by attaching the label "stiliaga." This facilitated the growth of youth agency.

However, this agency proved troublesome when it led young people to challenge the official discourse's demand for them to express full faith in the Party. This was perhaps most clearly visible in the consternation expressed by publicly involved young people over the differences between official claims and everyday life. While such disparity existed before Stalin's death, the prevalent ideology of Socialist Realism permeating official rhetoric encouraged individuals to work on themselves in order to view the world as it should be, not as it was.101 The Khrushchev government relaxed censorship and allowed the weakening of the Socialist Realist paradigm in its effort to use telling the truth about the problems of everyday life to mobilize society and impel the bureaucracy to action. ${ }^{102}$ The enthusiastic response of many young people, as illustrated by the correspondence sent to newspapers which cataloged a host of problems, nonetheless frequently did not result in satisfactory solutions.

Disappointments over the failure of truthful revelations to bring about meaningful reforms, combined with the gradual realization of the discontinuities between propaganda and reality, led to mounting disillusionment among some publicly engaged young people. A case in point is that of a young woman, "an energetic person" who was actively involved in public life in high school, but lost interest once in college because she did not see any "people really committed to Komsomol work." She stated that the "disorganized and uncultured" behavior of contemporary youth resulted from insufficient engaging free time activities: "Young people have nowhere to go." Now, her main interest was money: "Money is everything. Luxury and well-being, love and happiness." 103 While she chose to leave public life and retreat into private sphere, ${ }^{104}$ other young people sought to bring about reforms "from below" independently or even in opposition to the

100. Yurchak, Everything..., 174-183.

101. Jochen Hellbeck, Revolution on My Mind: Writing a Diary Under Stalin (Cambridge: Harvard University Press, 2006), 10-11.

102. For using truth as to achieve reforms, see P.L. Vail and A.A. Genis, 60-e: Mir sovetskogo cheloveka [The 1960s: The Soviet citizen's world] (Ann Arbor: Ardis, 1988).

103. See responses to surveys published in KP: B.A. Grushin, Chetyre zhizni Rossii v zerkale oprosov obshchestvennogo mneniia: ocherki massovogo soznaniia rossiian vremen Khrushcheva, Brezhneva, Gorbacheva i El'tsina v 4-kh knigakh [The four lives of Russia as mirrored in public opinion surveys: Notes on the mass consciousness of Russians in the times of Khrushchev, Brezhnev, Gorbachev and Yeltsin in four volumes]. Vol. 1, Zhizn' 1-ia, epokha Khrushcheva [The first life, Khrushchev's era] (M.: Progress-Traditsiia, 2001), 172-173.

104. For the retreat into private life, see Vladimir Shlapentokh, Public and Private Life of the Soviet People: Changing Values in Post-Stalin Russia (New York: Oxford University Press, 1989). 
government, exemplifying the dangers to the state of mobilized citizens. Perhaps the best case in point is that of V. E. Ronkin and his friends, who "believed in the ideals of the October Revolution." Ronkin thought that "the 'mess' that [he] saw around [him] represented only local problems," and participated in a Komsomol patrol in Leningrad that sought to "clean up the city" of hooligans and stiliagi. Over time, however, he and his patrol friends decided that the "mess" resulted from the Party's deviation from "true" socialism. They formed an underground circle dedicated to criticizing the Party's failure to live up to its ideals, and the state eventually jailed them as political dissidents. ${ }^{105}$ Such findings confirm the notion that ideological systems may have the most to fear from those who once fully accepted their tenets, and then experienced feelings of betrayal upon realizing the differences between claims and reality. ${ }^{106}$

\section{Conclusion}

Studying the public discourse of the youth press elucidates the point that the Thawera leisure campaign primarily utilized social activation and collective opprobrium for imposing social control, a move that was emblematic of the post-Stalin leadership's turn to infrastructural power in managing the country. By passing instructions on the organization of institutions dedicated to monitoring free time such as Komsomol bases and patrols, and directly reviling those labeled as deviant, the press played a critical role in the mobilization of symbolic violence on behalf of the Party, responding to Khrushchev's ideological concerns. In severely condemning the actions of those labeled delinquent, particularly after 1961, official rhetoric endeavored to exclude them from society while underscoring the standards of ideologically appropriate behavior for the rest of the youth. The Komsomol press, by insisting that all young communist citizens participate in institutions overseeing free time activities or at least engage in the public censure of purported deviants, enforced a discursive reinterpretation in the image of the New Soviet Person. In contrast to the model presented in the late Stalinist media of passive subjects who let state institutions take primary responsibility over policing "juvenile delinquency," Khrushchev-era newspaper discourse set the ideal of young activist citizens monitoring and controlling their fellows' everyday leisure behavior.

Nevertheless, press rhetoric proved riddled with ambiguities, with substantial uncertainty and potential for negotiation over identifying those who deserved to be set outside the boundaries of acceptability, especially relevant when the discourse experienced shifts. Furthermore, the Khrushchev state, de-emphasizing the previous, Manichean model, may have deliberately given a certain leeway to

105. Ronkin, Na smenu..., 56, 71-75, 186-212.

106. James C.Scott, Domination and the Arts of Resistance: Hidden Transcripts (New Hampshire: Yale University Press, 1990), 107. 
amorphous, complex youth who shared some of the characteristics of both New Soviet People and those labeled deviant, encouraging them to become "proper" citizens while permitting a measure of non-conformism; though a bone of contention among bureaucrats between hard-liners and those supporting more tolerant attitudes, sufficient support existed among the officialdom for opening up negotiating room to ensure a wide-ranging debate in the media. The resultant ambiguities, I suggest, undermined the cohesion of public discourse on the leisure campaign. Considerable scope existed for individual interpretation, and the process of searching for the ideologically appropriate way to behave, appear, think, and live, strengthened the impulse toward the formation of an autonomous identity and youth agency in the Thaw generation.

These unintended consequences, in my view, undermined the Party's legitimacy in the longue durée. The mounting willingness of young individuals to perceive and criticize the differences between propaganda and reality, to find their own way to conduct their lives and develop autonomous cultural practices, challenged the fundamental principle of model communists, full faith in the Party's ideological vision. The resultant ideological disillusionment likely played a fundamental part in the support for the reforms of perestroika among the publicly engaged Soviet urbanites whose formative years lay in the Khrushchev era.

University of North Carolina at Chapel Hill

tsipursk@email.unc.edu 